Ferdinand, Siarl and Flora Komlosi. "The Use of Hungarian and Serbian in the City of Szabadka/Subotica: An Empirical Study." Hungarian Cultural Studies. e-Journal of the American Hungarian Educators Association, Volume 10 (2017) DOI: 10.5195/ahea.2017.278

\title{
The Use of Hungarian and Serbian in the City of Szabadka /Subotica: An Empirical Study
}

\section{Siarl Ferdinand and Flora Komlosi}

\begin{abstract}
In this study Ferdinand and Komlosi analyze the use of Hungarian and Serbian in the city of Szabadka/Subotica, which is located in the Serbian region of Northern Vajdaság/Vojvodina. A mostly Hungarian speaking city for centuries, Szabadka/Subotica suffered the strong pro-Serbian language policy implemented by the Yugoslavian government from the end of the First World War until the dismantlement of Yugoslavia in the 1990s, which gave Hungarian and other local minority languages a second chance to survive. Nowadays, Szabadka/Subotica is home to two main language groups, southern Slavic languages such a Serbian and Croatian (over sixty per cent) and Hungarian (thirty three per cent). Although Ferdinand and Komlosi employed official figures from the Serbian censuses to determine the size of each group, the situation of each language was mapped through empirical observation of language use in informal conversations, in official signage, and in permanent as well as temporary commercial signage. The results show that the role of Serbian (mostly written in Latin script) is dominant in almost all spheres of public life and as a lingua franca among various groups. Nevertheless, Hungarian maintains a strong presence in the city, especially in the center and in its northwestern districts. In this paper, Ferdinand and Komlosi aim to contribute to a better general understanding of group dynamics in bilingual settings and, specifically, to provide a clearer view of the language situation in one of the Hungarian-speaking regions lost by the historic Kingdom of Hungary after World War I.
\end{abstract}

Keywords: Serbian, Hungarian, minority languages, bilingualism, language vitality

Biographies: Siarl Ferdinand is a Ph.D. candidate in Bilingual Studies at University of Wales Trinity St David in Lampeter. His main research interests include topics related to minority languages and cultures from Europe and Central Asia, such as language revitalization, language maintenance, and language death. He has previously published "Situation of the Csángó Dialect of Moldavia in Romania" in this journal

http://dx.doi.org/10.5195/ahea.2016.231.yeth_kernewek@yahoo.co.uk

Flora Komlosi received an MA in Bilingualism and Multilingualism from the University of Wales Trinity St David in Carmarthen. Her main research interests include language vitality, bilingualism, acquired helplessness in language acquisition, motivation in linguistics and students' learning style preferences. flora.komlosi@yahoo.co.uk

* In this paper, the geographical names of the Autonomous Province of Vajdaság/Vojvodina are given in their Hungarian form, followed by their form in Serbian (in Latin script), both of them official in Serbia. 
Ferdinand, Siarl and Flora Komlosi. "The Use of Hungarian and Serbian in the City of Szabadka/Subotica: An Empirical Study." Hungarian Cultural Studies. e-Journal of the American Hungarian Educators Association, Volume 10 (2017) DOI: 10.5195/ahea.2017.278

\section{Historical and Linguistic Introduction of the City of Szabadka/Subotica}

Szabadka (Hungarian) or Subotica (in Serbian and Croatian) is a city in northern Vajdaság/Vojvodina, an autonomous province of the Republic of Serbia. The region, which used to be inhabited mostly by Hungarians, formed part of the Kingdom of Hungary from the eleventh century until 1919, when it was ceded to Yugoslavia after the treaty of Trianon.

Szabadka/Subotica is first mentioned in 1391 as a small town in Hungary. Nowadays it has a population of more than 100,000 inhabitants (more than 140,000 counting all its rural districts), which makes it the second most populous conurbation in Vajdaság/Vojvodina after Újvidék/Novi Sad and thus one of the main cities of Serbia. Until the cession of Vajdaság/Vojvodina to Yugoslavia, imposed upon the Kingdom of Hungary by the Treaty of Trianon, the majority of Szabadka/Subotica's population were Hungarians (MacMillan, 2001: 269). However, since that time, the emigration of Magyars to Hungary and other countries and the arrival of thousands of Serbs and other ex-Yugoslavian nationalities into the region have changed considerably the composition of the population, as seen in Table 1 (Göncz and Vörös 2005: 192). Nevertheless, Hungarians continue to be the main ethnic group followed by three southern Slavic nationalities, namely Serbians, Croatians, and Bunjevci (see Graph 1).

\begin{tabular}{llllllllll} 
Year & Total & \multicolumn{2}{c}{ Hungarians } & Serbs & \multicolumn{3}{c}{ Germans } & \multicolumn{2}{c}{ Other/Unknown } \\
& Population & Total & $\%$ & Total & $\%$ & Total & $\%$ & Total & $\%$ \\
1880 & 62,556 & 31,592 & 50.5 & 2,904 & 4.6 & 1,828 & 2.9 & 26,232 & 42.0 \\
1910 & 94,610 & 55,587 & 58.5 & 3,514 & 3.7 & 1,913 & 2.0 & 33,596 & 35.5 \\
1931 & 100,058 & 41,401 & 41.4 & 9,200 & 9.2 & 2,865 & 2.9 & 46,592 & 46.5 \\
1941 & 102,736 & 61,581 & 59.9 & 4,627 & 4.5 & 1,787 & 1.7 & 34,741 & 33.9 \\
1948 & 112,194 & 51,716 & 46.1 & 11,617 & 10.4 & 480 & 0.4 & 38,381 & 43.1 \\
1961 & 75,036 & 37,529 & 50.0 & 9,437 & 12.6 & - & - & 28,070 & 37.4 \\
1971 & 88,813 & 43,068 & 48.5 & 11,728 & 13.2 & 218 & 0.2 & 33,799 & 38.1 \\
1981 & 100,516 & 44,065 & 43.8 & 13,959 & 13.9 & 97 & 0.1 & 42,395 & 42.2 \\
1991 & 100,386 & 39,749 & 39.6 & 15,734 & 15.7 & 138 & 0.1 & 44,765 & 44.6 \\
2011 & 105,681 & 34,511 & 32.7 & 31,558 & 29.9 & 199 & 0.1 & 39,413 & 37.3
\end{tabular}

Table 1: Historical distribution of the population of Szabadka/Subotica (based on Kocsis \& Kocsis-Hodosi 1998: 145 and Statistical Office of the Republic of Serbia 2012: 44)

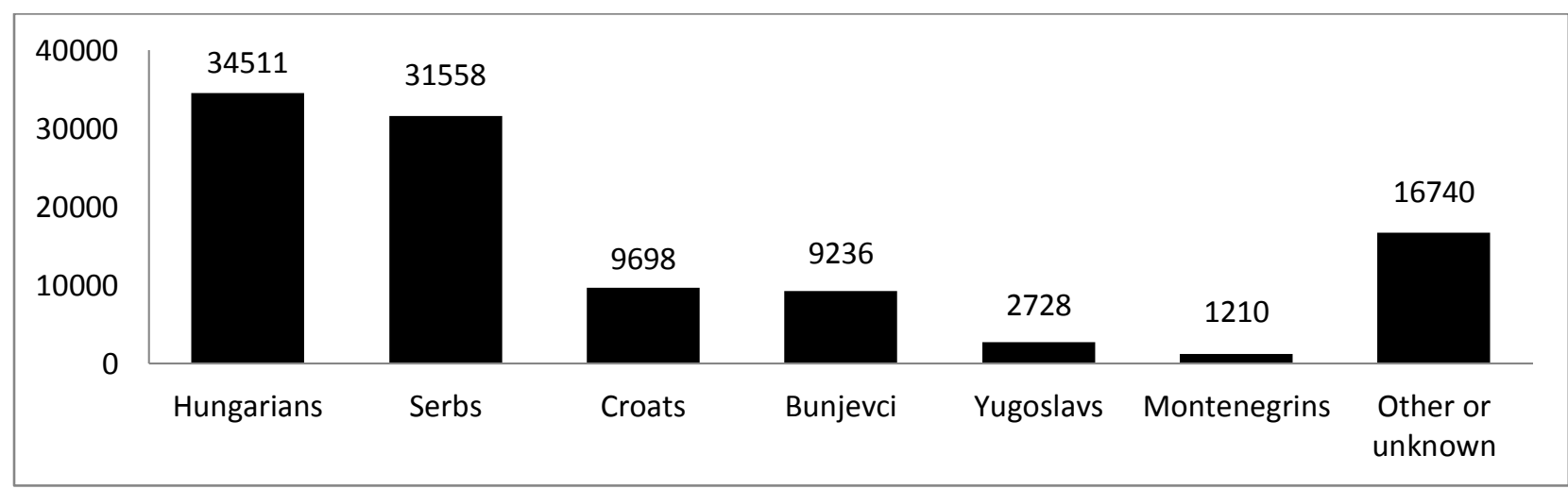

Graph 1. Distribution of the population by ethnicity

(Statistical Office of the Republic of Serbia 2012: 44). 
Ferdinand, Siarl and Flora Komlosi. "The Use of Hungarian and Serbian in the City of Szabadka/Subotica: An Empirical Study." Hungarian Cultural Studies. e-Journal of the American Hungarian Educators Association, Volume 10 (2017) DOI: 10.5195/ahea.2017.278

It can be said that knowledge of Serbian is universal among the inhabitants of Szabadka/Subotica. However, when the mother tongue of the people is considered, the panorama shows a multilingual city in which there are native speakers of more than fourteen languages (Statistical Office of the Republic of Serbia 2012: 44-45). Since many of the local nationalities speak Serbian or other southern Slavic languages and dialects, such as Croatian, Bunjevci, Montenegrin, and Bosnian as their mother tongue, Serbian in this broader sense has become the main language. Nevertheless, about one third of the people of Szabadka/Subotica, including about ninety-four per cent of the local ethnic Hungarians and a considerable number of members of other nationalities, have Hungarian as their mother tongue (Council of Europe 2009: 6). The attraction of non-Hungarian toward the Hungarian language in Vajdasag/Vojvodina can be explained by two main reasons. The first one has its origins in the region's history. Vajdaság/Vojvodina was a part of the Kingdom of Hungary for about a thousand years; therefore a number of families of different nationalities who had switched to Hungarian before the incorporation of Vajdaság/Vojvodina to Yugoslavia in 1919 may have maintained it as their family language. The second reason is related to personal circumstances, such as interethnic background and mixed marriages (Kocsis and Kocsis-Hodosi 1998: 147, 158). The members of the rest of minorities usually speak either their mother languages along with Serbian or Serbian only (See Graph 2).

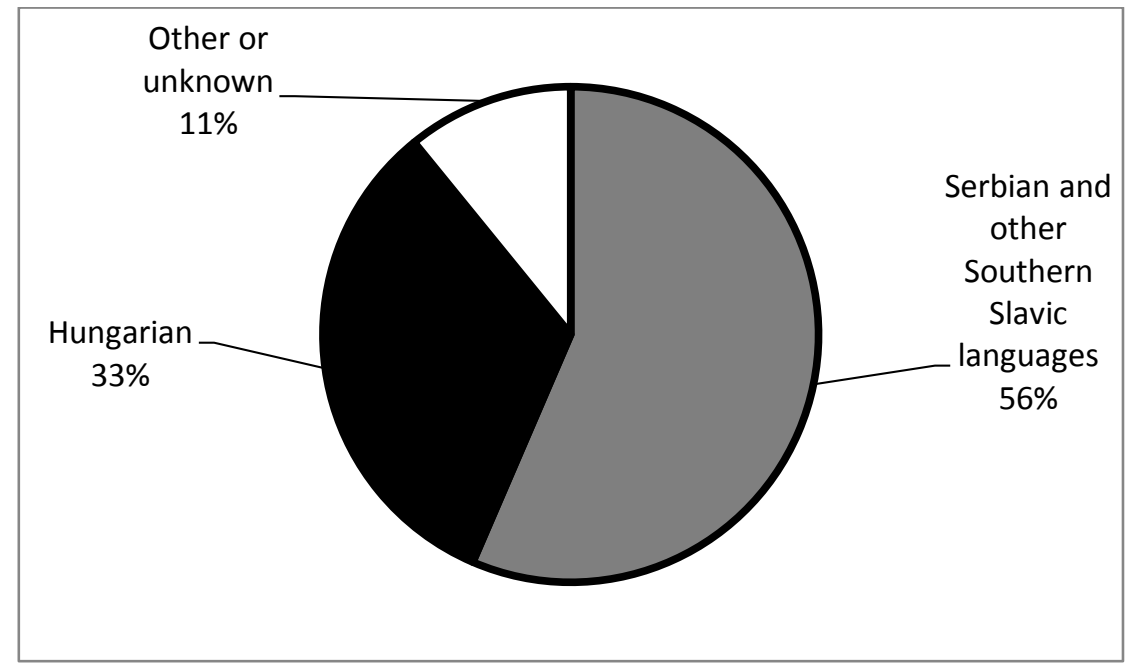

Graph 2. Distribution of the population of Szabadka/Subotica according to their mother tongue (Statistical Office of the Republic of Serbia 2012: 44)

\section{Language Policy and Minority Language Education in Yugoslavia and the Republic of Serbia}

The1919 treaty with the victorious Allies of World War I obligated the Kingdom of Serbs, Croats and Slovenes, as Yugoslavia was known before 1929, to protect minorities and to offer them the option of accepting their new nationality or declining and preserving their original nationality. In view of this situation and the potential danger of having a number of regions where the Yugoslavian/Serbian/Slavic sentiment was a minority, the state decided to take radical measures, the most ambitious being the transformation of education. To that end, the whole 
Ferdinand, Siarl and Flora Komlosi. "The Use of Hungarian and Serbian in the City of Szabadka/Subotica: An Empirical Study." Hungarian Cultural Studies. e-Journal of the American Hungarian Educators Association, Volume 10 (2017) DOI: 10.5195/ahea.2017.278

population was pressured into accepting education in Serbian, the official language of the community, regardless of their ethnicity or mother tongue (Göncz and Vörös 2005: 193-194, Anderson 1991: 84). As a result, the Hungarian education system was rapidly dismantled and minority classes set up at Serbian schools. Hungarian teachers and schoolbooks were lacking and enrolment was restricted. The number of secondary schools allowed to function in minority languages was very limited, most of them in German, Hungarian, Czech, and Slovak (Janjetović 2012: 71). Additionally, the state also encouraged ethnic Hungarians to emigrate to Hungary, deported Hungarian-speaking officials who had refused to take the oath of allegiance to the new regime, banned Hungarian political and cultural organizations, and suspended Hungarians' voting rights (Schubert 2011: 15). As a result of these measures, a growing percentage of Hungarians did decide to leave the country, while those who stayed in Vajdaság/Vojvodina were compelled to enroll their children in education only or mostly through the medium of Serbian. When the possibility to opt for Yugoslavia or for Hungary or Austria expired in 1921, the situation for minorities, including Hungarians, slightly improved since their voting rights were reestablished and the political parties and cultural societies of minorities were allowed again (Janjetović 2012: 71). Education, however, did not experience a much visible improvement. In fact, after 1950, schooling in minority languages continued its decline because of the decrease in the number of school-age children and as a result of legal measures, such as the one requiring a minimum of thirty students in order to start a class in a minority language. In the years before the collapse of Yugoslavia, the government in Belgrade implemented an ultra-nationalistic policy that had a very deleterious effect on the local Hungarians, since minorities were forbidden to establish their own education network and, at the same time, budgets to implement regional languages were drastically reduced (Arday 2000: 370). By 1999, eight decades after the partition of the historic Kingdom of Hungary, only about sixty per cent of the Hungarian children in Serbia pursued their education through the medium of Hungarian, mostly limited to primary school (Kocsis and Kocsis-Hodosi 1998: 158, Göncz and Ivanović 2011: 78, 79).

With the establishment of the independent Republic of Serbia in 2006, the position of language minority communities did improve. Although according to the current Constitution (2006), the Serbian language and Cyrillic script is in official use throughout Serbia (Article 10), this does not imply that the country is officially monolingual, since Article 79 states that all minorities have the right to maintain their culture, including their national languages and scripts along with Serbian. This legal situation allows minorities certain rights, such as to run their own schools, to have radio and television programs, or to be employed by the local and regional administration. In contrast within central Serbia, Vajdaság/Vojvodina's sociolinguistic situation is much more complex, as evidenced by the fact that its regional constitution, the Statute, declares the Serbian language and Cyrillic script as official, alongside a number of other local languages, namely Hungarian (in 31 municipalities), Slovak (in 13), Romanian (in 10), Ruthenian (in 6), Croatian (in 4) and Czech (in 1), with their respective scripts (Autonomous Government of Vojvodina 2016). This complexity is accepted by most inhabitants of the region, regardless of their ethnic belonging, with cases of open conflict among the various groups being relatively rare (Rácz 2012: 587). Despite the improvement in the situation of minorities during the last decade and the fact that the use of minority languages is protected by law, the successive evaluations of the application of the European Charter for Regional or Minority Languages (ECRML), signed by the Federal Republic of Serbia and Montenegro in 2005, found a number of its objectives unfulfilled, especially in the judicial, administrative and educational domains, such 
Ferdinand, Siarl and Flora Komlosi. "The Use of Hungarian and Serbian in the City of Szabadka/Subotica: An Empirical Study." Hungarian Cultural Studies. e-Journal of the American Hungarian Educators Association, Volume 10 (2017) DOI: 10.5195/ahea.2017.278

as adult education and the teaching of the history and the culture which is reflected by the regional or minority language (Council of Europe 2016: 42-43). Since Hungarians are the most numerous minority in Vajdaság/Vojvodina the chances of their being taught in their mother tongue, Hungarian, are better than those of most of the other minorities. Recent surveys show that between seventy and eighty per cent of Hungarian students at primary level attended institutions where Hungarian is either the only vehicular language or is taught alongside Serbian. Secondary education in Hungarian is also available at different institutions. In Szabadka/Subotica, there is a Hungarian-medium secondary school, Kosztolányi Dezső Tehetséggondozó Gimnázium, and at least seven other Serbian-Hungarian bilingual schools. Szabadka/Subotica is also a regional hub for Hungarian higher education. The local branch of the Faculty of Economics of the University of Novi Sad and the School of Civil Engineering offer a number of programs in Hungarian. However, the offer is so limited that only about twenty per cent of the Hungarian students are able follow programs in their mother tongue. This situation leads to an exodus of hundreds of Hungarian speaking students to Hungary, of whom only twenty per cent think they may return to Vajdaság/Vojvodina (Göncz and Ivanović 2011: 89, 90). Besides primary, secondary and tertiary education, Hungarian is also taught to students of other ethnicities and to adults in a number of other language schools and institutions, such as the Open University of Subotica. As shown, the situation is undoubtedly improving for minority languages and, particularly, for Hungarian. However, in spite of this relatively favorable setting, the committee of experts of the Council of Europe, stated that Hungarian education in Serbia faces some serious difficulties due to a general shortage of teachers and lack of enough programs in adult education (Council of Europe 2013: 17, Council of Europe 2016: 42).

\section{The Study: Design, Subjects, and Procedures}

The present study was carried out in terms of two interrelated perspectives. On the one hand, we observed and registered the language used by people talking in the street. On the other we obtained data on the use of Serbian (both in Cyrillic and Latin script), Hungarian, and other languages based on official signage and advertising. In order to collect data on the oral use of the languages involved, we chose certain strategic areas of the city where we noted down as discreetly as possible the language of passers-by's conversations. Some information was also obtained by asking shopkeepers and other individuals about the language behavior of their customers and people in general. This methodology did not invade people's privacy since the researchers never followed the speakers, and, therefore, the parts of the conversations that they heard were no more than a few seconds long, enough to simply determine the language but insufficient to identify the topic of the conversation or the people involved. The information based on public written signage was gathered by annotating the language and scripts used in 1) official signage, such as street names, directions, signs on public facilities, etc.; 2) permanent commercial signage (usually the name and type of business); and 3) provisional notices such as "back in 5 minutes," "out of service," etc., in shops and offices. For this study, publicity represented by trademarks, franchises, multinationals or other notices, such as those issued by the government or the city council, were not treated as temporary signage. The collection of data was carried out in various urban districts, namely the three districts comprising the city center, Centar, three districts in the southwest, Novo Selo, Gat and Ker, and three other districts, Dudova Šuma, Željezničko and Kertváros in the northeast (see Image 1). The election of these districts was based on several considerations. In a city like Szabadka/Subotica, as in most 
Ferdinand, Siarl and Flora Komlosi. "The Use of Hungarian and Serbian in the City of Szabadka/Subotica: An Empirical Study." Hungarian Cultural Studies. e-Journal of the American Hungarian Educators Association, Volume 10 (2017) DOI: 10.5195/ahea.2017.278

medium-sized cities and towns in central Europe, the center has a powerful attraction for the inhabitants of the outer districts. Therefore most of the social and economic life is concentrated in the streets around the city hall and it is there where there are more possibilities to study language habits of people of different language, social and ethnic backgrounds. Some of the districts situated northeast of the city center have a higher concentration of Hungarians, which is why Dudova Šuma, Željezničko and Kertváros were included in the study. The other side of the city, was represented by Novo Selo, Gat and Ker, in the southwest, where the percentage of nonSerbian speakers seems to be lower than elsewhere in the city. We collected data on August 10 and 11, 2016. On August 10th, we recorded the use of the written languages in shops, offices, publicity, notices and official signing. In the evening $(5 \mathrm{pm}-8 \mathrm{pm})$, we carried out the first round of observation of conversational language use. A second round of observation was also performed the following morning between 9 am and $11 \mathrm{am}$.

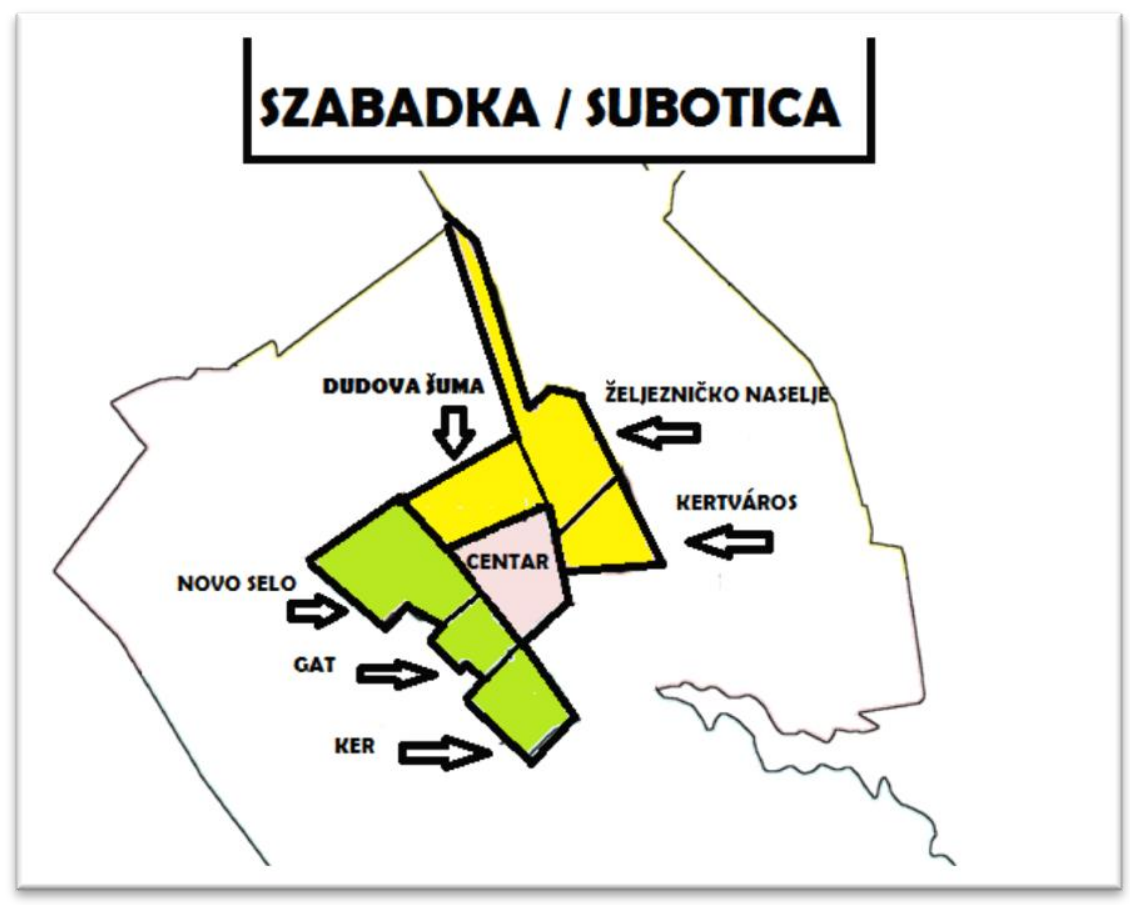

Image 1. Locations where the research was carried out.

\section{Linguistic Behavior in Informal Conversations}

The total number of conversations recorded was 175 . Most were noted down in the city center (120), followed by the northeastern districts (42) and the southwestern part of the city (13). As mentioned previously, the high number of conversations in the center fits well with the way of life of the inhabitants of the Szabadka/Subotica, who spend much of their free time in the streets of the central districts. Despite their similar distance to the city center, there were notable differences in the number of conversations in the northeastern and southwestern areas, which can be explained by the location of the Mlečna Market between the districts of Dudova Šuma (northeast) and Centar (city center). In every location, more oral Serbian was heard than Hungarian although there were some significant differences depending on the district. The behavior observed in the city center is quite similar to that observed in the southwest of 
Ferdinand, Siarl and Flora Komlosi. "The Use of Hungarian and Serbian in the City of Szabadka/Subotica: An Empirical Study." Hungarian Cultural Studies. e-Journal of the American Hungarian Educators Association, Volume 10 (2017) DOI: 10.5195/ahea.2017.278

Szabadka/Subotica, where Serbian is clearly over-represented. However, the northeast districts exhibit a stronger presence in Hungarian, which was heard in 38 per cent of the conversations, a rate higher than the 33 per cent of local native Hungarian speakers (See Graph 3).

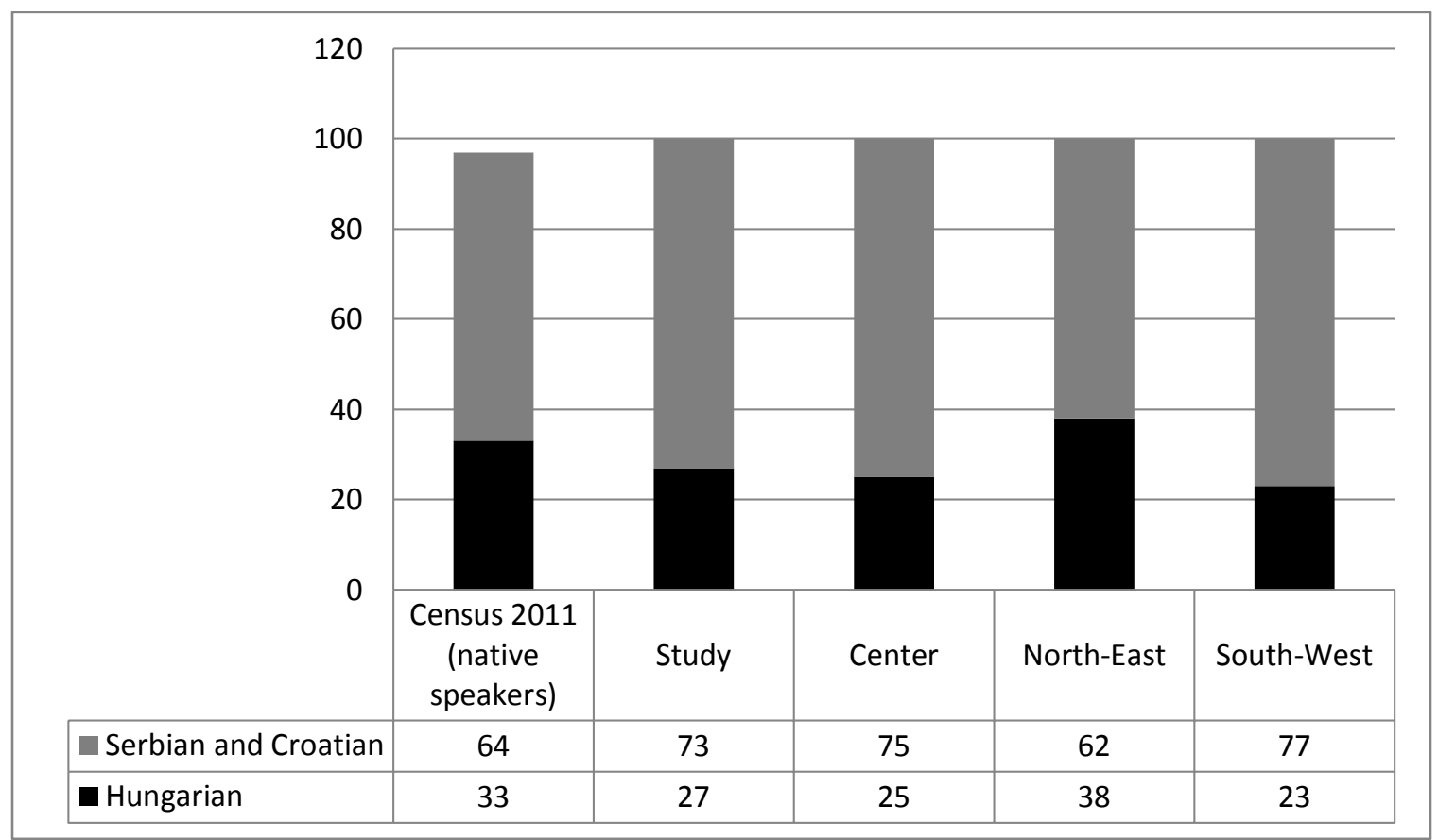

Graph 3. Serbian and Croatian and Hungarian native speakers (Census 2011) and percentage of conversations in those languages per area.

The relatively low rate of use of Hungarian in most parts of Szabadka/Subotica can be explained in terms of two main factors. On the one hand, as the results suggest, there is a higher concentration of Hungarian speakers in the districts situated in the north and east of Szabadka/Subotica. The other reason may be the adaptation of the Hungarian speaking population to a mostly Serbian-speaking environment. In fact, it was observed by the researchers that the language behavior of some people altered depending on who they were addressing. For example some Hungarian speakers switched to Serbian when addressing strangers in a business environment, or asking for directions. This fact was also confirmed by some Serbian-Hungarian bilingual shop assistants and market sellers who stated that most Hungarian customers initially make their requests in Serbian although once the Hungarian competence of both customer and seller is established Hungarian is usually preferred. In municipal and regional facilities, such as railway and bus stations, tourist offices, city hall, etc., where most officials are bilingual, it was observed that many Hungarian speaking customers and visitors made their requests in Hungarian straight away. 
Ferdinand, Siarl and Flora Komlosi. "The Use of Hungarian and Serbian in the City of Szabadka/Subotica: An Empirical Study." Hungarian Cultural Studies. e-Journal of the American Hungarian Educators Association, Volume 10 (2017) DOI: 10.5195/ahea.2017.278

\section{Written Use of Languages in Businesses}

Szabadka/Subotica can be considered the most attractive town of northern Vajdaság/Vojvodina for a number of reasons. On the one hand, it is the most important commercial center. Customers and potential customers visit Szabadka/Subotica not only from the nearby towns and villages but also from Hungary (the border is only $30 \mathrm{~km}$ away), attracted by the variety of products offered and by the lower prices when compared to Hungary. Tourism also plays a prominent role in attracting international visitors since the city possesses an impressive number of art-nouveau monuments and it is only eight kilometers (five miles) from Palics/Palić, a resort designed in the early twentieth century situated by the Nature Park of Lake Palics. A final reason that usually draws people from Hungary to Szabadka/Subotica is that many local families have members on both sides of the border established by the Treaty of Trianon in 1920, so family visits are relatively frequent. A notable effect of this continuous flow of visitors to the city is the overrepresentation of Hungarian in the permanent signage of shops and offices, ranging from thirty-three to forty-eight per cent, while Hungarians currently represent, as mentioned, only one third of the local population. This fact is particularly evident in signs of lawyers' offices and jewelers.

In the city center, Centar, approximately half of the business advertise themselves in several languages, most commonly Serbian and Hungarian. Due to the touristic character of the district, almost forty per cent of the shops display permanent signs in foreign languages, although this is often manifested by the use of native forms of such international words as Italian "pizzeria" (instead of the Serbian nuuepujalpicerija or the Hungarian pizzéria), French "restaurant" (instead of the Serbian pecmopaн/restoran or the Hungarian étterem) or the English "pharmacy" (always alongside the Serbian апотека/apoteka and, very often, the Hungarian gyógyszertár) (Graph 4/A). By contrast, temporary signage, such as the example on Image 2, is much closer to the real language knowledge and use of the local population. Serbian (in Latin script) is used in basically all the businesses situated in the central districts, while Hungarian is used in slightly less than a third of the shops. There is no provisional signage in English, Italian or other foreign languages, and Serbian Cyrillic script is reduced to a few 'curiosities' (See Graph 4/B). Interestingly, some businesses include Hungarian along with Serbian in permanent and sometimes even in temporary signage although the owners and/or sales assistants are Serbian speakers with no or very limited command of Hungarian. There may be two main reasons for this behavior. On the one hand, there is what could be called "adaptation of the business to the local reality," since despite certain prejudices, preferences or sociopolitical situations, Hungarian is still the language spoken by the single most numerous ethnic group in Szabadka/Subotica. The other reason may be considered purely economic. Advertising the shop in Hungarian may attract the attention of both local Hungarians and tourists, most of them from Hungary and without any knowledge of Serbian. 
Ferdinand, Siarl and Flora Komlosi. "The Use of Hungarian and Serbian in the City of Szabadka/Subotica: An Empirical Study." Hungarian Cultural Studies. e-Journal of the American Hungarian Educators Association, Volume 10 (2017) DOI: 10.5195/ahea.2017.278

\section{Centar - City Center}

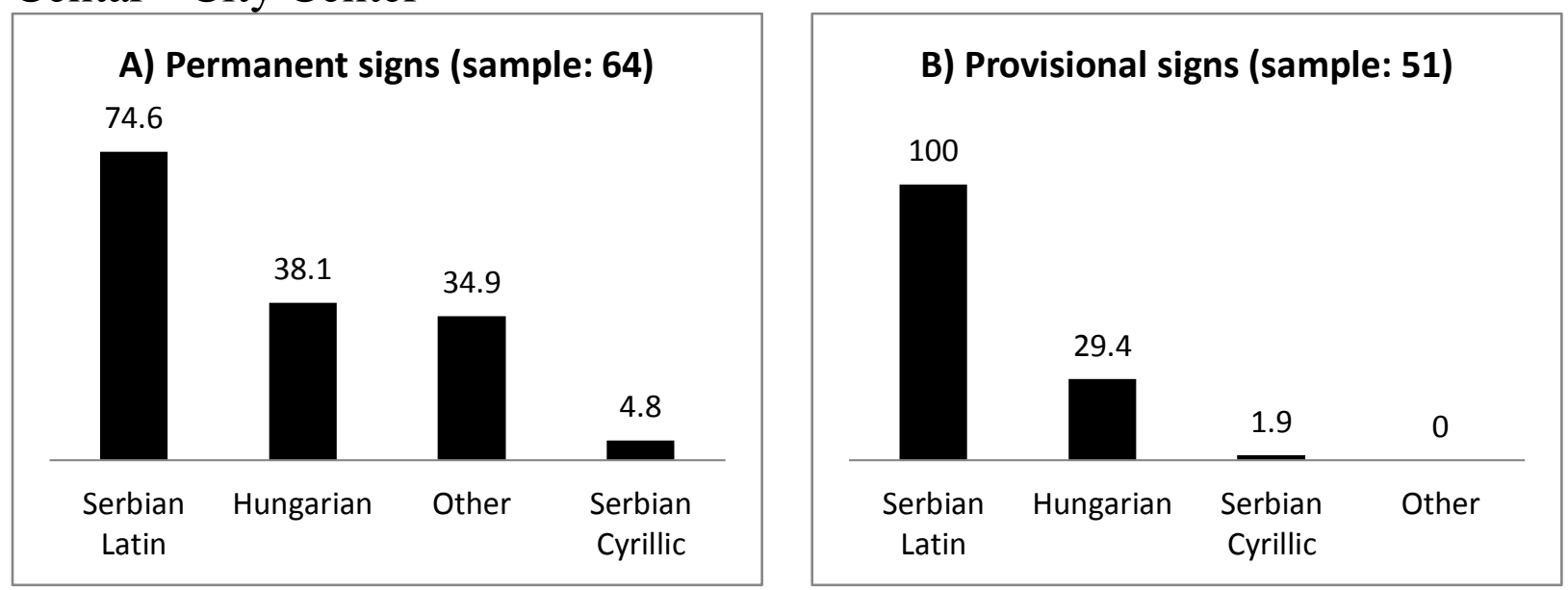

Graph 4. Use of languages in business environments in the center of Szabadka/Subotica.

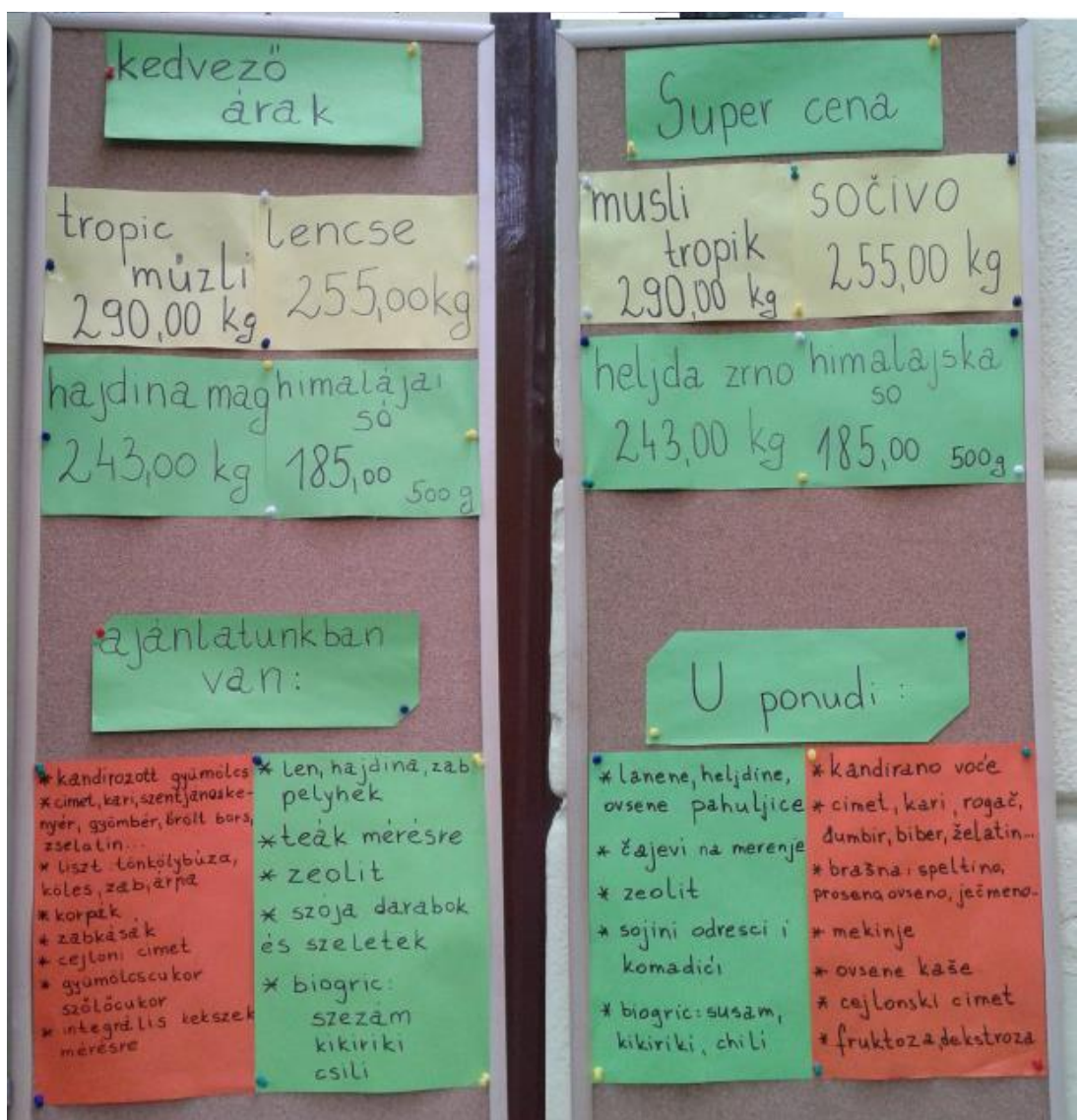

Image 2. Temporary signage in Hungarian and Serbian with Latin script

As shown in Graph 5/A, the presence of Hungarian in permanent signs in the shops of Dudova Šuma, Željezničko, and Kertváros (northeast) is higher than in the rest of the city since almost half of them use Hungarian for promoting themselves. Serbian (in Latin script) is, as expected, the most often found language in shops and offices while foreign languages are much 
Ferdinand, Siarl and Flora Komlosi. "The Use of Hungarian and Serbian in the City of Szabadka/Subotica: An Empirical Study." Hungarian Cultural Studies. e-Journal of the American Hungarian Educators Association, Volume 10 (2017) DOI: 10.5195/ahea.2017.278

less frequent than in the city center, and Serbian (in Cyrillic) is almost non-existent. Temporary signage is reduced to two forms, either Serbian (in Latin script) or Hungarian. However, the percentages of use of the languages in provisional signage are somewhat anomalous since, despite the extensive use of Hungarian in informal conversations (38 per cent, see Graph 3) and in permanent signage ( 47 per cent), the language is only employed in 1 out of 4 acts of informal communication (Graph 5/B). This could be because of the assumption that Serbian is the only language understood by all one's neighbours, making the use of Hungarian (or another language) redundant.

\section{Dudova Šuma, Željezničko and Kertváros - Northeast}

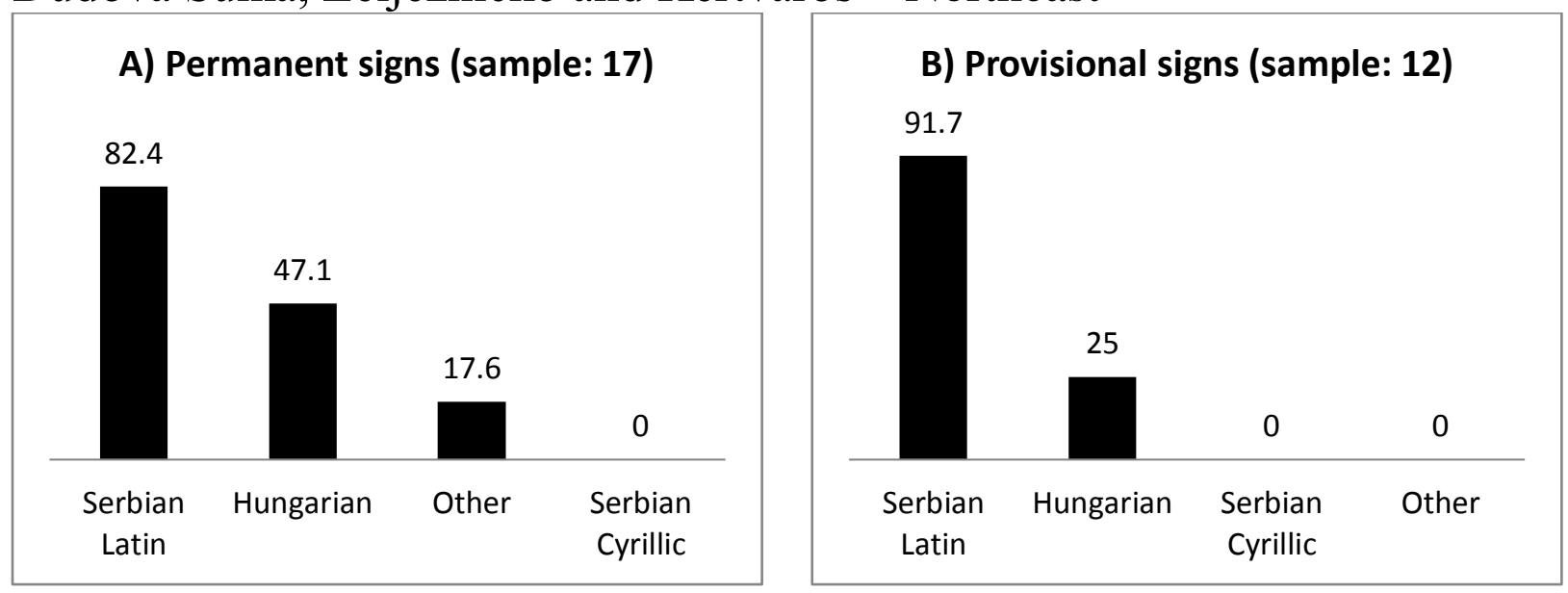

Graph 5. Use of languages in business environments in the northeast of Szabadka/Subotica.

The districts situated in the southwest of Szabadka/Subotica, in which the percentage of conversations in Serbian was notably higher than in the rest of the city, show a similar pattern in both the permanent and the temporary signage in shops (See Graph 6/A and B). Once again, the use of Serbian (in Latin script) is almost universal while Hungarian is employed less often than in the rest of the city. The use of other languages is virtually limited to the words Hotel, Restaurant or Zimmer Frei (German for "Rooms Available"). One difference from other districts is the relatively high percentage of signs written in Cyrillic script (10 per cent in permanent signs and over 7 per cent in temporary signs). This anomaly could be explained, as some business people in the districts of Novo Selo, Gat and Ker suggested, by the fact that a significant percentage of people from other Serbian speaking regions of former Yugoslavia (where the use of the Cyrillic alphabet is much more common) are currently settled in the southwest of Szabadka/Subotica. 
Ferdinand, Siarl and Flora Komlosi. "The Use of Hungarian and Serbian in the City of Szabadka/Subotica: An Empirical Study." Hungarian Cultural Studies. e-Journal of the American Hungarian Educators Association, Volume 10 (2017) DOI: 10.5195/ahea.2017.278

\section{Novo Selo, Gat and Ker - South West}

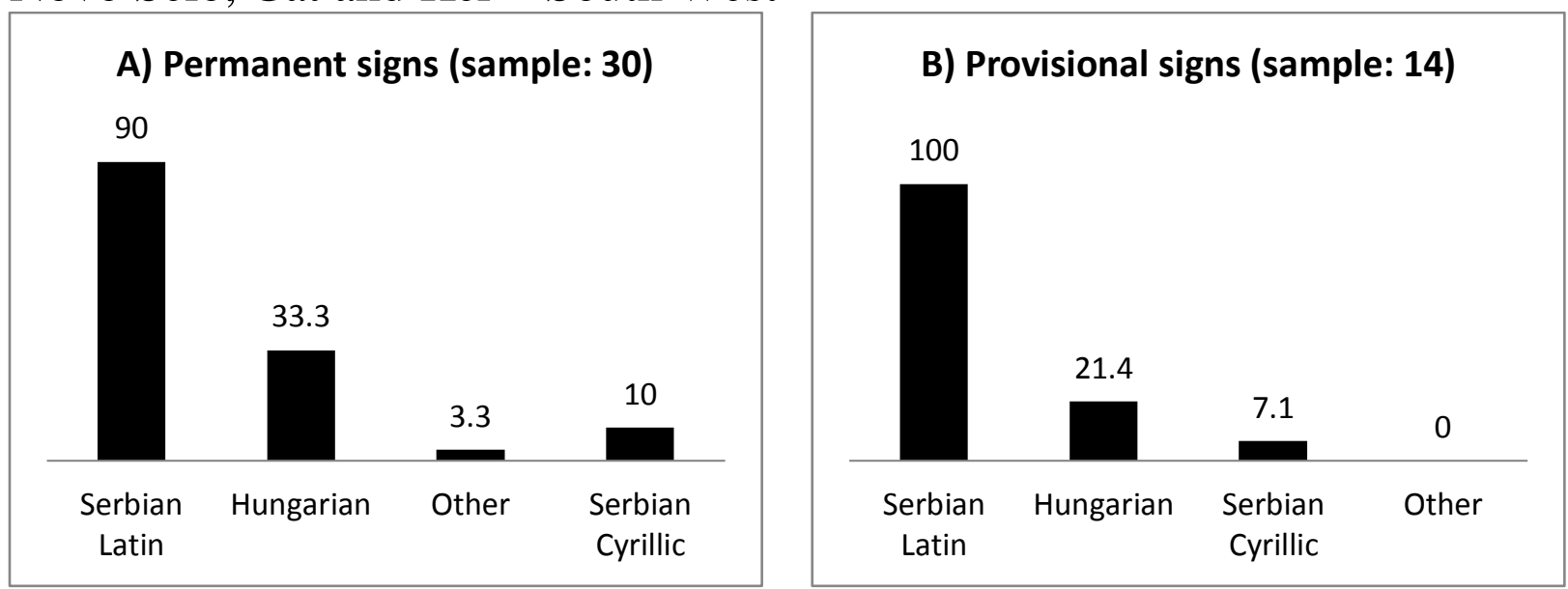

Graph 6. Use of languages in business in the south west of Szabadka/Subotica (per percentage).

\section{Use of Languages in Official Signage}

Since Serbian (in both Latin and Cyrillic script) and Hungarian are official languages of Szabadka/Subotica (Subotica City Council 2016) local authorities are obliged to use them in official communications and public signage (Autonomous Government of Vojvodina 2016). In compliance with this rule, most public signage, such as the names of facilities and utilities, streets, squares, parks, etc., is given in Serbian (Cyrillic script), Serbian (Latin script) and Hungarian (Image 3/A). In the city center, where most public buildings and monuments are located, some directional signs also include English alongside the three official languages (Image 3/B). There are, additionally, a few examples of older signs on which the street name appears only in Serbian (in Latin script), while the only cases contrary to the official/general local multilingualism are found on the outskirts of Szabadka/Subotica, where directional signs are provided only in Serbian (in Cyrillic script) and in a major foreign language, English (Image $3 / \mathrm{C})$.

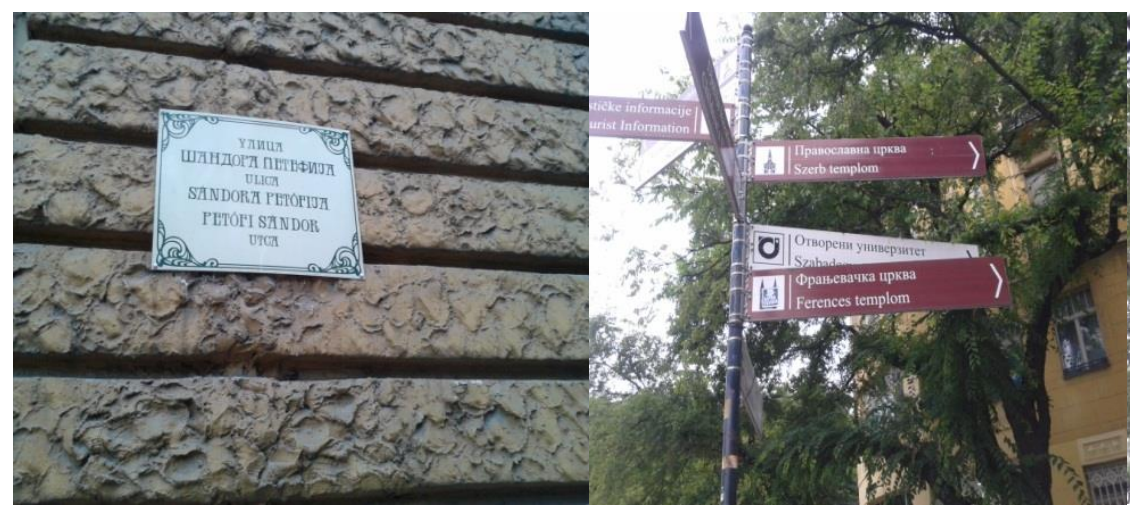

A) Typical street sign in Serbian (Latin and Cyrillic) and Hungarian
B) Directional signs in the city center in Serbian (Latin and Cyrillic), Hungarian and English

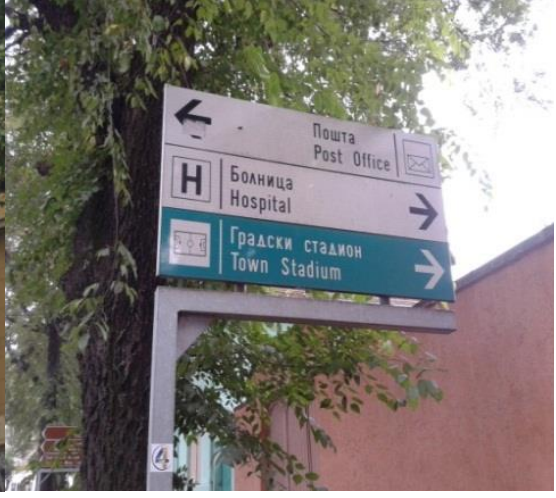

C) Directional signs on the outskirts of Szabadka/Subotica in Serbian (Cyrillic) and English only

Image 3. Street signage in Szabadka/Subotica 
Ferdinand, Siarl and Flora Komlosi. "The Use of Hungarian and Serbian in the City of Szabadka/Subotica: An Empirical Study." Hungarian Cultural Studies. e-Journal of the American Hungarian Educators Association, Volume 10 (2017) DOI: 10.5195/ahea.2017.278

\section{Conclusion}

The reshaping of borders after World War I in 1920 cut off the local Hungarian-speaking population of Szabadka/Subotica from most of the Hungarian population of central Europe. The strong pressure exercised for decades by the Yugoslavian (Serbian) authorities, the high level of migration of local Hungarians to Hungary and other richer countries, and the arrival of large numbers of Serbian speakers from other regions of Yugoslavia and its successor states in Vajdaság/Vojvodina is rapidly changing the profile of the city's population. Nowadays, what was once a Hungarian-speaking majority in Szabadka/Subotica has become a minority of about one third of the total population. This development over the last century or so, has made the position of Hungarian in the region potentially vulnerable. Nevertheless, in spite of every difficulty, the Hungarians in this region seem to have maintained their language quite well. It is reported that more than ninety percent of the area's ethnic Hungarians (Magyars) still have Hungarian as their mother tongue (Council of Europe 2009: 6). Moreover, there are also hundreds of individuals of many ethnicities locally, including Serbians, Croatians, Roma (Gypsies), Germans and others who have Hungarian as their mother tongue or as their second language (Statistical Office of the Republic of Serbia 2012: 44). This language maintenance is evident in the conversations in the streets, since more than a quarter of them were in Hungarian. After the breakup of Yugoslavia in the 1990s, Hungarian was given a second chance to survive in Serbia. Its recovered status as an official language has improved the visibility of Hungarian in all parts of Szabadka/Subotica. Examples of monolingual signage are exceptionally rare reduced to a few old street signs and some direction posts in the outskirts of the city, while the employment of Hungarian in permanent and/or temporary commercial signage reaches almost fifty percent of the businesses in some districts. Moreover, the Serbian education system has allowed an increase in the quantity and quality of Hungarian in the classroom from kindergarten to university. Despite all this progress, there are some domains where the use of Hungarian is still underdeveloped, such as in the justice system or in tertiary and adult education (Council of Europe 2016: 42-43). However, the main threat to the survival of Hungarian in Szabadka/Subotica may not be connected to its legal and social situation in Serbia but to population movements: both the exodus of local Hungarians to other places and the influx of Serbian speakers to Vajdaság/Vojvodina (Ferdinand 2016: 73-74). Since there is no solution to the problem of migration, at least from the local perspective, it is very important for local Hungarian clubs and societies to continue the promotion of Hungarian as a language useful and valuable for the local population and for the promotion of local culture and heritage. This strategy would, in turn, enhance the Hungarian language's prestige (Agirrezabal Pertusa 2009: 30-31). It is also important to uncouple the language from political ideologies, such as secessionism and nationalism, since the failure to do so may only result in the alienation of a high percentage of Szabadka/Subotica's local population. (cf. Welsh Assembly Government 2011: iv). For its part, the Serbian government must continue its work of providing education in, and enhancing the possibilities of using minority languages, in this case Hungarian, in every official domain since it would help all the local linguistic minorities to consider themselves an integral part of the country in which they live and avoid the explosion of problems endured by Yugoslavia in the early 1990s, which were mainly the result of inflamed nationalistic sentiment (Smith 2009: 107). 
Ferdinand, Siarl and Flora Komlosi. "The Use of Hungarian and Serbian in the City of Szabadka/Subotica: An Empirical Study." Hungarian Cultural Studies. e-Journal of the American Hungarian Educators Association, Volume 10 (2017) DOI: 10.5195/ahea.2017.278

\section{Works Cited}

Agirrezabal Pertusa, Lore (ed.). 2009. The Basque Experience 1. Some Keys To Language And Identity Recovery. Eskoriatza: Garabide.

Anderson, Benedict, 1991. Imagined Communities: Reflections On the Origin and Spread Of Nationalism. London: Verso.

Arday, Lajos (ed.). 2002. Magyarok a Délvidéken, Jugoszláviában ['Hungarians in Yugoslavia']. Budapest: BIP.

Autonomous Government of Vojvodina. 2016. Official Use of Languages and Scripts in the AP Vojvodina. http://www.puma.vojvodina.gov.rs/etext.php?ID_mat=207

Council of Europe. 2009. Application of the Charter in Serbia. ECRML (2009) 2. Council of Europe: Strasbourg.

- 2013. Application of the Charter in Serbia. ECRML (2013) 3. Council of Europe: Strasbourg.

- 2016. Application of the Charter in Serbia. ECRML (2016) 1. Council of Europe: Strasbourg.

Göncz, Lajos and Ivanović, Josip. 2011. Linguistic Minorities in Serbia (with Special Emphasis to Education in Minority Languages). Pedagogijska istraživanja, 8 (1): 71-102.

Göncz, Lajos and Vörös, Ottó. 2005. "Hungarian in the former Yugoslavia (Vojvodina and Prekmurje)." Hungarian Language Contact Outside Hungary. Ed. Anna Fenyvesi. Amsterdam: John Benjamins: 187-240

Ferdinand, Siarl. 2016. "Situation of the Csángó Dialect of Moldavia in Romania." Hungarian Cultural Studies. E-Journal of the American Hungarian Educators Association, Volume 9: 72-89.

Janjetović, Zoran. 2012. "National Minorities in Yugoslavia 1918-1941." Review of Croatian History 8-1: 61-75

Kocsis, Károly. and Kocsis-Hodosi, Eszter. 1998. Ethnic Geography of the Hungarian Minorities in the Carpathian Basin. Budapest: Hungarian Academy of Sciences.

MacMillan, Margaret. 2001. Paris 1919: Six Months That Changed the World. New York: Random House.

Rácz, Krisztina. 2012. "By the Rivers of Babylon: Multiculturalism in Vivo in Vojvodina Vajdaság." Jezikoslovlje 13.2: 585-599.

Ristović, Nenad. 2015. "Latin and Vernacular Relations in the Eighteenth and Nineteenth Centuries: The Serbian Case." Latin at the Crossroads of Identity. Eds. Gábor Almási and Lav Subarić. Leiden: Brill: 256-277.

Schubert, Frank N. 2011. Hungarian Borderlands: From the Habsburg Empire to the Axis Alliance, the Warsaw Pact, and the European Union. London: Continuum.

Smith, Anthony D., 2009. Ethno-Symbolism and Nationalism: A Cultural Approach. Abingdon: Routledge.

Statistical Office of the Republic of Serbia. 2012. Ethnicity. Data by Municipalities and Cities. Belgrade: Statistical Office of the Republic of Serbia.

Subotica City Council. 2016. Суботица у Бројевима [Szabadka/Subotica in Figures]. http://www.subotica.rs/index/page/id/47/lg/cp/

Welsh Assembly Government. 2011. A Living Language: A Language for Living. A Strategy for the Welsh Language. Cardiff: Welsh Assembly Government. 